(2) Open Access Full Text Article

ORIGINALRESEARCH

\title{
How Much Does It Cost for a Surgical ICU Bed in a Public Hospital in India
}

\author{
Thean Singh \\ Jawahar SK Pillai $\mathbb{D}$ \\ Mukunda C Sahoo \\ Department of Hospital Administration, \\ AlIMS, Bhubaneswar, India
}

Correspondence: Jawahar SK Pillai

Email jawahardr@yahoo.com
Introduction: Activity-based costing $(\mathrm{ABC})$ is a costing technique that identifies the activities in an organization and assigns the cost to the activities based on the actual resources consumed for each activity. The method was used to ascertain the cost of surgical intensive care unit (SICU) bed in an institute of national importance, such as All India Institute of Medical Sciences (AIIMS), Bhubaneswar, from June 2019 to February 2021.

Objective: The present study aimed to ascertain the cost of SICU beds per day by the ABC technique. The different elements of cost were analyzed. The cost for selected patients in the SICU unit was calculated by preparing a cost sheet based on the elements of cost and studying the existing charging system.

Methods: A total of 38 cases were selected from the departments of General Surgery, Urology, Orthopedics, and Plastic surgery. Based on the ABC technique, the activity map was developed for SICU (cost center), and the time consumed together with resources for each activity was calculated with respect to human resources, consumables, medicines, and overheads. Thus, the total cost incurred by the hospital for SICU beds per day was estimated using the cost sheet analysis.

Results: The cost was calculated to be Rs. 11,241/- per day (155 USD) against the hospital charge of Rs. 35/- $(<0.5$ USD) for general patients and Rs. 1000/- for private ward patients. Exchange Conversion Rate used is 1 USD $=72.60$ INR $(2020-21)$.

Conclusion: The public sector hospitals in India provide health-care services for free and at a subsidized rate; hence, ascertaining the cost incurred by the hospital is necessary for policy decisions.

Keywords: activity-based costing, SICU, costing, cost accounting, facility management costing

\section{Introduction}

A major concern in India in the health sector is the increasing healthcare cost. India has spent $1.28 \%$ GDP on its healthcare in 2018, which is among the lowest healthcare budget worldwide. ${ }^{1}$ The increased cost is due to the increased usage of sophisticated hospital equipment (magnetic resonance imaging (MRI), computed tomography (CT), and linear accelerator), skilled workers (training cost), medicines (newer antibiotics and anticancer drugs), and consumables (quality standard recommendations, such as care package) during the past decade. ${ }^{2-5}$ Therefore, understanding the cost at different activity levels of a hospital is crucial for economic control. ${ }^{6-9}$ Hospitals use several standard costing methodologies, such as traditional costing (volume-based), micro-costing, and standard costing; one of the approaches used is activity-based costing $(\mathrm{ABC}) .^{10-14}$ 
$\mathrm{ABC}$ is defined as the approach to the costing and monitoring of activities that involve tracing the resources used and costing the final outputs. The resources used are assigned to activities, and the activities are assigned to cost objects based on the estimated consumption. The cost objects utilize cost drivers to attach the activity costs to outputs - Chartered Institute of Management Accountants, London (CIMA). ${ }^{15-18}$

$\mathrm{ABC}$ identifies the organizational activities and assigns the cost of each activity resource to the products and services as per their precise consumption of each. The indirect costs (overhead) are assigned by tracing the activities to the final outcome. As a result, the organization can precisely estimate the costs of its products individually and services in order to identify and eliminate the unprofitable elements and lower the prices of the overpriced services. ${ }^{19-21}$

Studies in England and Germany have addressed enhancing the patient-based costing in diagnostic-related groups (DRG) system and stated that $\mathrm{ABC}$ must be used in the costing systems in DRG. ${ }^{22}$

Bahadori et al examined $\mathrm{ABC}$ in the health-care center. ${ }^{23}$ A case study of a health-care center in Iran affiliated with Tehran university was a descriptive crosssectional study based on the financial data of 2010. The ABC methodology was applied by the software developed using MS-Excel as follows: Step 1 - Formation of the group (experts from economy, finance, equipment, and healthcare); Step 2 - Structural assessment of organization by defining the units of activity; Step 3 - Segregation of the centers of activity into three categories, such as overhead service department, intermediate service department, and final service department; Step 4 - Determination of output per unit of activity; Step 5 - Identification of the process of each output in the units of activity; Step 6 Allocation of cost based on the unit of activity; Step 7 Overhead cost allocation.

All India Institute of Medical Sciences (AIIMS), Bhubaneswar, Odisha, was established in 2012 by the act of the Indian Parliament under Pradhan Mantri Swasthya Suraksha Yojana (PMSSY) scheme to correct the regional imbalances in healthcare. AIIMS, Bhubaneswar, operated with 840 beds and has 14 surgical intensive care unit (SICU) beds functioning with $>95 \%$ occupancy rate at any given point in time. In addition, 53 ICU beds are available for Medical Specialty and Surgical Super Specialties (Neurosurgery, CTVS; Cardiothoracic \& Vascular Surgery, and GI; Gastrointestinal Surgery). The cost of treatment in SICU is subsidized and presently charged at Rs. 35/- $(<0.5$ USD) per day. The ABC study for costing the SICU bed would aid in planning for pricing strategy in the future. To the best of our knowledge, this is the first study undertaken to ascertain the cost of SICU beds per day in an institute of national importance using the $\mathrm{ABC}$ technique (ascertain the cost of services provided by the hospital) in order to analyze the various elements of cost, calculate the cost for selected patients in by preparing a cost sheet based on the elements of cost, study the existing charging system, and recommend modifications to the hospital.

\section{Methods}

The study was conducted in SICU at AIIMS, Bhubaneswar, from June 2019 to February 2021. The subjects included in the study were patients admitted to the SICU during the study period. The inclusion criteria included patients admitted to the SICU, and the exclusion criteria included patients admitted to the SICU for $<48 \mathrm{~h}$, and those whose length of hospital stay was $>10$ days to avoid bias while arriving at a workable cost as extremely spread-out data were not favorable. Also, patients with a prolonged length of stay in the Neurosurgery, CTVS, and GI Surgery departments and with a high complication rate were excluded. ${ }^{18,20,21}$

\section{Prospective Observational Design}

The SICU at AIIMS has 14 beds, located on the third floor of the main hospital block. A total of 38 patients were prospectively followed up to ascertain the cost of the surgical bed per day using the $\mathrm{ABC}$ technique. The informed consent was obtained from all the participants in accordance with the declaration of Helsinki. The activities with respect to human resource charges, consumables, medicines, laboratory investigations, diet expenses, patient linen, oxygen cost, administrative charges, and miscellaneous charges were mapped using direct observation, interviewing health-care workers (HCWs), focus group discussions, data from case sheets, office records, and accounts department. Miscellaneous charges, such as electricity, telephone, central sterile supply department (CSSD), SICU building cost, and equipment, were accounted for in the final cost sheet. The collected data were transcribed on an MS-Excel sheet to calculate the cost of SICU beds per day., ${ }^{7,9}$

Primary data were collected from doctors, nurses, and administrative staff by direct observation and focus group discussions, while secondary data were extracted from medical records. 
The study population included 38 patients. The other personnel, doctors, nurses, and administrative staff, were a part of the study to arrive at the final costing by calculating the time spent by each of them in the patient care services.

\section{Tools Used for Analysis Were Percentage Method and Cost Sheet Analysis}

The patients included in this study were followed up from admission to SICU till the transfer out of SICU. The average length of stay in normal circumstances (no delay in shifting out the patients to respective wards in view of nonavailability of ward beds to service these patients on few occasions; however, any circumstances as non-availability were not raised during the current study) was 3.8 days.

The patients included in the study were monitored with respect to human resource consumption, consumables used, and the amount of medicines consumed. The $\mathrm{ABC}$ is prudent in arriving at a realistic amount chargeable to the patients admitted to the SICU, especially in an institute where humanitarian considerations are a significant part of decision making. ${ }^{6,7}$ At AIIMS, Bhubaneswar, all the medicines and consumables are supplied free of cost for all below the poverty line (BPL: The Government of India has categorized its citizens based upon economic status to provide them with subsidized rations and welfare schemes) patients, subsidized rates for employee health Scheme (EHS: The health institutes in India provide health benefits to its employees and their dependents at a subsidized rate) patients, and proportionally charged for private patients admitted to the SICU. The private patients are charged more than the general, BPL, and EHS patients as per the existing charging system in place by which private patients cost less money to the hospital as they pay out of their pocket. The critical elements of costs included in the final total cost were human resource charges (Tables 1-4), consumables, medicines, laboratory investigations, diet expense, patients' linen, administrative overheads, and miscellaneous charges that include electricity, telephone, CSSD, SICU building cost, and equipment/machine costs. ${ }^{12,18,21}$ Thus, the logistics and accounting of the entire organization were considered. The time spent by the doctors in the SICU and other supporting staff, every item/consumable used for each patient, the number of laboratory/radiological tests, the usage of mechanical ventilators, the electricity consumed, and other miscellaneous charges were also considered for each patient. After estimating the costs of the activities, the cost of every activity was attributed to the respective product, such that the product resources were consumed. The wastage/errors were incorporated in the current study by eliminating the unwanted activities to be costed. The activities in SICU were traced for optimization by an activity map.

The time taken by doctors, nurses, dieticians, infection control nurses, nursing superintendent, nursing attendants, and sanitary attendants in SICU was estimated. The salary for each activity was also calculated. The administrative overheads were also calculated, which included the salaries of the senior officials, information technology (IT) personnel, office attendants, and administrative and accounts staff.

Miscellaneous charges included electricity, telephone charges, CSSD costs, SICU building costs, and equipment/ machines. These were also considered in calculating the final total cost of SICU surgical beds per day. The next step was to identify the time spent by the personnel for each case. The time spent by the personnel for each case was identified and the average was calculated. The consumables used in the SICU, the medicines used, and the laboratory investigations for each patient were also considered while calculating the expenditure for each patient. ${ }^{17}$

\section{Results}

Among the cost allocated to manpower, the salary of nursing officers encompassed the major head accounting

Table I Patient Sample $(n=38)$ Distribution

\begin{tabular}{|c|c|c|c|c|c|c|c|c|c|c|c|}
\hline $\begin{array}{l}\text { Serial } \\
\text { No. }\end{array}$ & Department & $\begin{array}{l}\text { No. of } \\
\text { Patients }\end{array}$ & Male & Female & $\%$ & $\begin{array}{l}\text { Mean } \\
\text { (Age) }\end{array}$ & $\begin{array}{l}\text { SD } \\
\text { (Age) }\end{array}$ & General & BPL & EHS & Private \\
\hline I & General Surgery & 22 & 15 & 7 & 57.90 & 47.08 & 14.98 & 15 & 7 & 0 & 0 \\
\hline 2 & Orthopedics & 5 & 3 & 2 & 13.15 & 45.80 & 23.87 & 3 & 2 & 0 & 0 \\
\hline 3 & Urology & 8 & 8 & 0 & 21.05 & 57.50 & 7.80 & 4 & 3 & 0 & I \\
\hline 4 & Plastic Surgery & 3 & 2 & I & 7.90 & 42.33 & 11.67 & 2 & I & 0 & 0 \\
\hline 5 & Total & 38 & 28 & 10 & 100.00 & 49.39 & 15.12 & 24 & 13 & 0 & I \\
\hline
\end{tabular}

Abbreviations: BPL, below poverty line; EHS, employee health scheme. 
Table 2 Human Resources: Average Cost

\begin{tabular}{|c|c|c|c|c|c|}
\hline $\begin{array}{l}\text { Serial } \\
\text { No }\end{array}$ & Personnel & $\begin{array}{r}\text { Salary per Day } \\
\text { in INR }\end{array}$ & $\begin{array}{r}\text { Salary per Day } \\
\text { in USD }\end{array}$ & $\begin{array}{l}\text { Standard } \\
\text { Deviation }\end{array}$ & $\begin{array}{r}\text { Coefficient of } \\
\text { Variation }\end{array}$ \\
\hline 1 & Faculty (I) & 115.21 & 1.59 & 30.25 & 0.26 \\
\hline 2 & JR (Academic and Non-academic) (I) & 105.00 & 1.45 & 20.75 & 0.19 \\
\hline 3 & JR Dedicated (I) & 367.26 & 5.06 & 70.57 & 0.19 \\
\hline 4 & SR (Academic and Non-academic) (I) & 149.82 & 2.06 & 38.80 & 0.25 \\
\hline 5 & PDF (Anesthesia) (I) & 524.26 & 7.22 & 31.25 & 0.05 \\
\hline 6 & Senior Nursing Officer (I) & 98.87 & 1.36 & 21.00 & 0.21 \\
\hline 7 & Nursing Officer (10) & 2359.98 & 32.51 & 650 & 0.27 \\
\hline 8 & Dietician (I) & 45.00 & 0.62 & 6.75 & 0.15 \\
\hline 9 & Infection Control Nurse (I) & 24.08 & 0.33 & 7.09 & 0.29 \\
\hline 10 & Nursing Superintendent (I) & 96.00 & 1.32 & 16.58 & 0.17 \\
\hline II & Sanitary Attendant (3) & 228.85 & 3.15 & 52.83 & 0.23 \\
\hline 12 & Hospital Attendant (3) & 307.00 & 4.23 & 51.68 & 0.16 \\
\hline 13 & Administrative Charges & 359.00 & 4.94 & 83.12 & 0.23 \\
\hline 14 & Total & 4780.33 & 65.84 & 1080.67 & 0.22 \\
\hline
\end{tabular}

Abbreviations: JR, junior resident; SR, senior resident; PDF, post-doctoral fellowship; (), the number of personnel visiting the patient.

Table 3 Miscellaneous Expenditure

\begin{tabular}{|l|l|r|r|r|r|}
\hline Serial No & Miscellaneous Expenditure & INR & USD & $\begin{array}{r}\text { Standard } \\
\text { Deviation }\end{array}$ & $\begin{array}{r}\text { Coefficient of } \\
\text { Variation }\end{array}$ \\
\hline 1 & Electricity charges & 40.16 & 0.55 & 9.25 & 0.23 \\
2 & Telephone charges & 3.03 & 0.04 & 0.80 & 13.43 \\
3 & CSSD & 47.50 & 0.65 & 12.89 & 0.28 \\
5 & SICU Building cost & 97.40 & 1.34 & 632.32 & 0.13 \\
6 & Equipment's & 4088.00 & 56.31 & 0.15 \\
\hline
\end{tabular}

Abbreviations: CSSD, central sterile and supply department; SICU, surgical intensive care unit.

Table 4 Final Cost Sheet

\begin{tabular}{|c|c|c|c|c|c|c|}
\hline $\begin{array}{l}\text { Serial } \\
\text { No }\end{array}$ & Particulars & $\begin{array}{r}\text { Amount in } \\
\text { INR }\end{array}$ & $\begin{array}{r}\text { Amount in } \\
\text { USD }\end{array}$ & Percentage & $\begin{array}{l}\text { Standard } \\
\text { Deviation }\end{array}$ & $\begin{array}{r}\text { Coefficient of } \\
\text { Variation }\end{array}$ \\
\hline I & Human resources & 4780.33 & 65.84 & 42.52 & 1080.67 & 0.22 \\
\hline 2 & Drugs & 525.00 & 7.23 & 4.69 & 43.23 & 0.08 \\
\hline 3 & Laboratory charges & 568.00 & 7.82 & 5.05 & 61.33 & 0.10 \\
\hline 4 & Consumables & 852.00 & 11.74 & 7.57 & 82.40 & 0.09 \\
\hline 5 & Linen and Laundry & 89.25 & 1.23 & 0.8 & 12.50 & 0.14 \\
\hline 6 & Diet charges & 150.00 & 2.07 & 1.33 & 20.00 & 0.13 \\
\hline 7 & Miscellaneous charges & 4276.09 & 58.90 & 38.04 & 765.84 & 0.17 \\
\hline 8 & Total & $\mathrm{II}, 240.67$ & 154.83 & 100.00 & 2065.97 & 0.18 \\
\hline
\end{tabular}

for Rs. 2359.98/- (USD 32.51). A total of Rs. 4780/- (USD 65.84) per day was spent on the manpower.

Among the miscellaneous charges, the cost of equipment was the major head (accounted for maximum $\%$ of the cost as shown in Table 3), amounting to Rs. 4088/(USD 56.31), followed by the building cost of Rs. 97/-
(USD 1.34). The life of the equipment was considered to be 10 years with a scrap value @ 5\% on the cost price, annual insurance @ 1\% on the cost price, and the annual cost of spares with maintenance@ $@ 5 \%$ on the cost price in arriving at the final cost. Similarly, the life of the SICU building was considered to be 100 years 
with a salvage value @ 10\% and maintenance at the final cost.

As per the final cost calculation sheet, the human resource charges $(42.52 \%)$ and miscellaneous charges (38\%) accounted for the major head.

The above study carried out at AIIMS, Bhubaneswar, is the only study in India to estimate the cost per day for an SICU in a public sector hospital using the ABC technique.

In the above study, the major driver of costs in SICU is the manpower expense, which accounts for $42.52 \%$, followed by miscellaneous charges at $38.04 \%$ (includes electricity, telephone, CSSD, building, and equipment costs).

\section{Discussion}

A study published in the International Journal of Management in 2015 concluded that the major cost driver of about $44 \%$ was attributed to the building costs in both the ICUs. The current study ascribed human resource cost as the primary cost driver accounting for $42.82 \%$. This could be attributed to the fact that the current study is undertaken in a public sector hospital. Hence, the building costs (real estate costs) can be discounted compared to the private sector. Reportedly, the running costs of SICU and RICU (Respiratory ICU) are Rs. 27,371 and Rs. 31,183, respectively, compared to the current study with respect to SICU of Rs. 11,162.75, owing to the difference in costing techniques and sectors. $^{24}$

Another study published in the Medical Journal of Chile in 2013 estimated approximately 1,00,000 Chilean pesos (Rs. 9892.96) per day hospitalization cost similar to Rs. $11,162.75$ in the current study. ${ }^{25}$

The various methodologies, such as traditional costing and micro-costing, are $\mathrm{ABC}$ techniques that portray costing are allocated to various activities. In the existing scenario of increasing health-care costs, cost accounting and costing are critical tools that highlight cost drivers. The cost control methods can take a cue from such studies and take measures to contain excessive expenditure. Since the salary component in the public sector hospital is high for nurses and other staff in the public sector hospital in India compared to the private sector, ascertaining the cost is imperative. The ICU is a cost center, and many costly sophisticated pieces of equipment are utilized; their operation and maintenance are also challenging and costly.

\section{Conclusion}

AIIMS, Bhubaneswar is a public sector hospital and teaching institute that caters largely to patients belonging to the lower socioeconomic status. The charges to patients are minimal and no special charges for SICU. The current study ascertained the cost of SICU bed as Rs. 11,241/per day (USD 155) compared to the hospital charge of Rs. 35/- $(<0.5$ USD) for general patients and Rs. 1000/(USD 13.77) for private patients. An ABC model was followed, which analyzed the activities involved, the time consumed for each activity, and the resources consumed. The percentages of expenses under different heads were outlined in the cost sheet. The various expenditure heads identified were manpower charges @ 42.52\%, consumables charges@7.57\%,drug charges@4.69\%, and lab charges@5.05\%. The total cost of SICU beds in a public hospital in India was calculated as Rs. 11,241/per day (USD 155).

We hope that this study could provide the data for policymakers while planning for pricing strategies in public hospitals.

\section{Disclosure}

The authors report no conflicts of interest for this work.

\section{References}

1. IBEF (Indian Brand Equity Foundation). Available from: https:// www.ibef.org/industry/healthcare-india.aspx. Accessed September 22,2021

2. Narci HO, Ozcan YA, Sahin I, Tarcan M, Narci M. An examination of competition and efficiency for hospital industry in Turkey. Health Care Manag Sci. 2015;18:(4):407-418.

3. Udpa S. Activity-based costing for hospitals. Health Care Manage Rev. 1996;21(3):83-96. doi:10.1097/00004010-199622000-00009

4. Chan YC. Improving hospital cost accounting with activity-based costing. Health Care Manage Rev. 1993;18(1):71-77. doi:10.1097/ 00004010-199324000-00008

5. Canby J. Applying activity-based costing to healthcare settings. Healthc Financ Manag. 1995;49(2):50-56.

6. Dwivedi R, Chakraborty S. Development of an activity-based costing model for a government hospital. Uncertain Suppl Chain Manag. 2015;3(1):27-42. doi:10.5267/j.uscm.2014.9.003

7. Pillai JS, Rajalekshmi M. A study on costing of neurosurgery procedure at a public hospital in India. JMSCR. 2019;7(03). doi:10.18535/ jmscr/v7i3.158

8. Yereli AN. Activity-based costing and its application in a Turkish university hospital. AORN J. 2009;89(3):573-576, 9-91. doi:10.1016/j.aorn.2008.09.002

9. AccountingTools. Activity-based costing definition; 2021. Available from: https:/www.accountingtools.com/articles/2017/5/14/activitybased-costing. Accessed September 22, 2021.

10. Lahiff C, Cournane S, Creagh D, et al. Factors predicting the hospital episode costs of emergency medical admissions. Eur J Intern Med. 2014;25(7):633-638. doi:10.1016/j.ejim.2014.06.004

11. Cao P, Toyabe S, Kurashima S, Okada M, Akazawa K. A modified method of activity-based costing for objectively reducing cost drivers in hospitals. Methods Inf Med. 2006;45(4):462-469. doi:10.1055/ s-0038-1634085 
12. Aird B. Activity-based cost management in health care another fad? Int J Health Care Qual Assur. 1996;9(4):16-19. doi:10.1108/ 09526869610124182

13. Everaert P, Bruggeman W, Sanac De Creus G. From ABC to time-driven ABC (TDABC) - an instructional case. J Account Educ. 2008;26(3):118-154. doi:10.1016/j.jaccedu.2008.03.001

14. Stouthuysen K, Demeere N, Roodhooft F. Time-driven activity-based costing in an outpatient clinic environment. Health Policy. 2009;92 (2-3):296-304. doi:10.1016/j.healthpol.2009.05.003

15. CIMA. Definition of activity based costing. CIMA official Terminology; 2005. Available from: http://www.cimaglobal.com/ Documents/ImportedDocuments/cid_tg_activity_based_costing_ nov08.pdf.pdf. Accessed September 22, 2021.

16. Eldenberg L, Kallapur S. Changes in hospital service mix and cost allocations in response to changes in medicare reimbursement schemes. J Account Econ. 1997;23:31-51. doi:10.1016/S01654101(96)00447-8

17. Gujral S, Dongre K, Bhindare S. Activity-based costing methodology as tool for costing in hematopathology laboratory. Indian J Pathol Microbiol. 2010;53(1):68-74. doi:10.4103/0377-4929.59187

18. Kaplan R, Johnson H. Relevance Lost: Rise and Fall of Management Accounting. Boston: Harvard; 1987.

19. Maheshwari SN. Management Accounting and Financial Control. 16th ed. New Delhi: Sultan Chand Publishers; 2015.
20. Ridderstolpe L, Johansson A, Skau T, Rutberg H, Ahlfeldt H. Clinical process analysis and activity-based costing at a heart center. $J$ Med Syst. 2002;26(4):309-322. doi:10.1023/A:1015816703951

21. Lievens Y, van den Bogaert W, Kesteloot K. Activity-based costing: a practical model for cost calculation in radiotherapy. Int $J$ Radiat Oncol Biol Phys. 2003;57(2):522-535. doi:10.1016/S0360-3016(03) 00579-0

22. Vogl M. Improving patient-level costing in the English and the German 'DRG' system. Health Policy. 2013;109(3):290-300. doi:10.1016/j.healthpol.2012.09.008

23. Bahadori M, Babashahy S, Teymourzadeh E, MostafaHakmzadeh S. Activity based costing in health care center: a case study of Iran. Afri J Bus Manag. 2012;6(6):2181-2186.

24. Kundury KK, Mamatha HK, Rao D. Assessing the patient care expenses and cost per bed of a medical intensive care unit (MICU) of a tertiary care teaching hospital using cost block method. Int J Manag. 2015;6(12):59-70.

25. Sandra Alvear V, Jorge Cateros G, Juan Jara M, Patricia Rodriuez C. Activity-based costing methodology to manage resources in intensive care units. Med J Chile. 2013;141(11):1371-1381.
Risk Management and Healthcare Policy

\section{Publish your work in this journal}

Risk Management and Healthcare Policy is an international, peerreviewed, open access journal focusing on all aspects of public health, policy, and preventative measures to promote good health and improve morbidity and mortality in the population. The journal welcomes submitted papers covering original research, basic science, clinical \& epidemiological studies, reviews and evaluations,

\section{Dovepress}

guidelines, expert opinion and commentary, case reports and extended reports. The manuscript management system is completely online and includes a very quick and fair peer-review system, which is all easy to use. Visit http://www.dovepress.com/testimonials.php to read real quotes from published authors. 